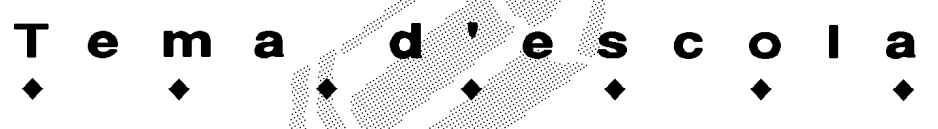

\section{LA FOTOGRAFIA HISTÒRICA COM A MITJÀ PER APRENDRE}

\author{
Antoni Gavaldà Torrents (coord.). Didàctica de les Ciències Socials. URV \\ Josep Casanovas Prats. Didàctica de les Ciències Socials. Universitat de Vic \\ Albert Macaya Ruiz. Didàctica de l'Expressió Plástica. URV \\ M. Àngels Ollé Romeu. Didàctica de la Llengua i la Literatura. URV \\ Agustí Salvat Altés. Didàctica de les Ciències Experimentals. URV
}

\section{La fotografia als textos escolars ahir}

És conegut que els llibres de fa anys -d'abans de la democràcia, per fixar un tall prou estudiat-tenien poques imatges i que aquestes eren encarades tant a omplir el text de sabers tancats com a mostrar epopeies glorioses en el cas de les unitats dels llibres d'història. Cal considerar que ambdós perfils, esbiaixats, eren l'expressió convincent que la imatge només il.lustrava. En el primer cas facilitava alleugerir llibres basats a formular preguntes i a donar respostes, on el saber no es posava mai en qüestió i on les veritats fluïen concatenades amb imatges banals, intranscendents, per omplir espais. En el segon cas, en els llibres d'història la imatge tenia un sentit del tot pervers, intentant transmetre guanyadors per sobre de vençuts, glòries "nacionals" enfront de "sinistres i malvats republicans de tota mena i condició". Altrament, en les imatges dels llibres de text hi havia una unió entre els dos poders de l'Estat: l'espasa i la creu.

Hem fet aquest preàmbul, volgudament sinòptic, per reflectir que la fotografia de base històrica -i tot el que no signifiqués text- tenia una determinada utilitat, en el fons considerada de segona. La fotografia -i per extensió la il.lustració que es posava als llibres de text- pretenia ser un mer complement de la lliçó o unitat. La il.lustració, en aquest context, significava la visualització del que volia transmetre un text més o menys encertat. És cert que la manipulació era més acusada en les disciplines interpretatives -enteneu història, geografia...-, atès que es buscava tant el recitat de les respostes com l'assimilació visual amb els herois de l'època en detriment de la interpretació. Sigui com sigui, la fotografia complia o bé un paper de comparsa o una distorsió descarada amb finalitats polítiques partidistes.

La fotografia, en aquest context, era una excusa, a la qual no es treia profit educatiu. Lligat en aquest context ni la fotografia, ni el document, ni la filmina, ni la transparència, etc. agafaren carta de naturalesa. Les lliçons, en general, eren calcades d'una enciclopèdia a una altra, fixant que el fet de repetir i de recitar no faltessin, d'igual forma que el de copiar i el de subratllar, buscant en un format de llibreta que el dibuix i la còpia complementessin un saber gens participatiu i d'escassa qualitat.

\section{El possible tractament de la fotografia avui a l'ensenya- ment primari}

Estem convençuts que un saber no s'aprèn si no s'entén i s'interpreta el que hi ha publicat o visualitzat, si no es qüestiona el mateix coneixement, si no es discuteix, si no es verbalitza en les paraules d'un mateix, en allò que els experts han anomenat transposició didàctica, $\mathrm{i}$ sobretot, si no es practica. És allò que els mestres amb criteri diuen en altres paraules "que ho han entès". Amb aquests bagatges podem dir que el tractament de la fotografia, com el d'altres aprenentatges que requereixen pràctica, ha entrat ben poc en el context escolar de Primària, bàsicament per dos motius aliens $i$ alhora complementaris, que considerem essencials denunciar:

Perquè la cultura de l'esforç i d'estudi dels alumnes ha decaigut, en lloc d'estímuls externs que desenfoquen la visió reconeguda que per aprendre cal voler aprendre. I que això, inexcusablement, requereix treball.

Perquè l'educació primària en molts casos suposa un trencament amb l'etapa anterior, la d'educació infantil, on la pràctica era la base d'un aprenentatge eficaç. Al parlar, discutir, decidir, manipular, construir, fer i desfer, presentar inferències o estimacions per ser contrastades de l'educació infantil es passa, a primària, en força casos, a uns sabers massa concentrats en llibres, desfigurant a poc a poc una pràctica que perd pistonada.

Partint d'aquestes premisses -que evidentment admeten matisos- s'ha arribat a considerar la pràctica com un complement d'una teoria, on el llibre de text com a saber immutable s'ha erigit en el saber dels sabers. I de quina pràctica parlem quan parlem de pràctica? Pràctica seria el saber que l'alumne ha de fer seu amb estudi i manipulació d'objectes i instruments, amb estudi i discussió del que s'ha observat, amb estudi i verbalització del que s'ha vist i comprovat, amb estudi i com- 


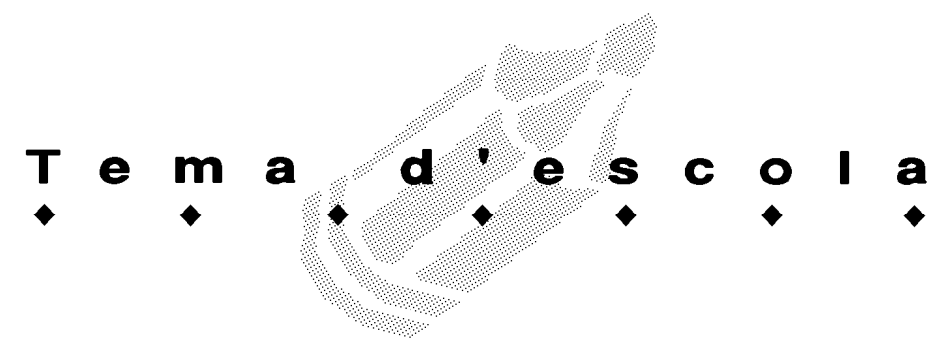

prensió per diferenciar l'essencial de l'accessori, amb estudi i aportació personal, com a eix indispensable perquè la pràctica esdevingui creativa. És en aquesta situació que la fotografia pot i ha d'ajudar a incorporarse a una pràctica reflexiva, encara que no única.

I per què la fotografia? Doncs perquè és un material que a cada casa hi és present i pot entrar a l'escola de la mà dels alumnes; perquè pot servir per a fixar l'interès en allò que s'està treballant; perquè fa que l'alumne participi d'un projecte d'una forma més activa; perquè es pot reproduir, a la mida que vulguem, per un mòdic preu i posar-la a l'abast del conjunt dels alumnes de la classe; perquè el saber de l'entorn exterior, fixat en aquesta fotografia única, implica que l'alumne vegi i entengui que hi ha una relació amb el saber transmès del llibres des de la ciència; perquè la varietat de possibles situacions a partir de diverses fotografies enriquirà el ventall de reflexió a l'entorn del concepte treballat; i finalment perquè l'alumne trobarà sentit al saber escolar al comprendre que els sabers de les disciplines no són compartiments tancats, i que la relació entre elles és del tot essencial.

El treball amb la fotografia a l'escola, per tant, presenta una variabilitat d'actuacions, i això fa que l'entenguem des de tres vessants diferenciades, tot i que poden ser en alguns casos complementàries i concatenades:

- La fotografia incita a treballar un determinat ítem en profunditat, i aporta referències complementàries a les imatges de què disposem, que s'adeqüin a la pretensió del que es pretenia aconseguir.

- La fotografia és un complement d'un centre d'interès que volem treballar amb més qualitat, per ajudar a lligar un tema escolar amb el context extern conegut de qualsevol matèria.

- La fotografia ajuda a reformular alguns continguts i creences a partir de qüestions quotidianes que per als alumnes poden semblar perennes, immutables.

\section{Bases on sustentar-se per introduir la fotografia a l'escola amb més decisió}

No som els primers -ni serem de ben segur els darrers- que intentem aportar reflexió respecte de l'entrada de la fotografia a l'escola. Les pautes d'anàlisi pioneres de Santos Guerra (1984) o les Jornades Antoni Varés de Girona, avui en ple funcionament, aporten llum al tema, i són un eix transversal del que estudiem: el primer per fer un anàlisi suggerent de com entrar en el món de la fotografia escolar, i el segon, per la diversitat contextual del tema. La imatge, en paraules de Tenorio (1995), mai no és neutra. Brown (1975) va escriure que a partir de les imatges fixes s'aprenen conceptes abstractes. Significà també que la utilitat de les imatges a l'ensenyament venia fixada per la capacitat de proporcionar conceptes com moviment, rapidesa, profunditat, temps o temperatura, i seria dels primers a abordar que el fet d'escollir les fotografies hauria de ser obra del mestre i dels mateixos alumnes, amb imatges portades expressament, qüestió que nosaltres abordarem més endavant. Fontcuberta (1990) aporta una síntesi de la percepció visual, estudiada per l'escola alemanya de la Gestalt, interessada a saber com s'agrupa i s'organitza un conjunt d'estímuls visuals perquè siguin percebuts com un tot. Resseguint les lleis de la Gestalt, per la lectura d'una imatge es troben:

- La proximitat -entesa com que els elements de prop prefiguren l'agrupació, i afecten tant l'espacialitat com la temporalitat.

- La similitud -quan uns components són similars en aspectes com la mida, la forma, el color, tendeixen a ser vistos com relacionats o agrupats.

- La continuïtat -l'absència d'interrupcions entre elements visuals implicarà que es vegin com a relacionats o agrupats.

- El tancament-quan les línies i formes incompletes però que són familiars faciliten que es vegin com a agrupades en línia contínua, bé recta o corba.

- La bona forma -entesa com la capacitat visual d'organitzar el conjunt buscant estabilitat, equilibri, significat i seguretat.

Sota aquests paràmetres manifesta que cal tenir present que la fotografia pot induir a diverses respostes dels subjectes que l'observen. Afegeix que l'experiència visual depèn no només del que es mira, sinó del que es busca en aquesta mirada, o sigui de la influència passada que hi aportem.

Campuzano (1992) presenta, en el mateix sentit, un esquema interpretatiu per a l'anàlisi de la imatge fixa. El dissecciona en tres nivells: el tècnic, el formal i el nivell del significat. Mentre el primer el basa en coneixements específics de tecnologia audiovisual, el formal pretén identificar els elements i estudiar la funció social en una imatge concreta. Seria en el tercer que abordaria una proposta d'anàlisi del que hi ha a la imatge, el que no hi és i el que hi és encara que no ho sembli.

En general, la majoria de reflexions parteixen de l'anàlisi d'una àrea educativa. Les tres àrees que han generat més literatura sobre com abordar aquest tema són les Ciències Socials, la Plàstica i la Llengua. La resta, en canvi, han tingut poca incidència a presentar un discurs sobre les possibilitats de la fotografia. Talment hi ha excepcions. Una de fa una sèrie d'anys ens la proporcionà Bazalguette (1991), donant pistes de com abor- 


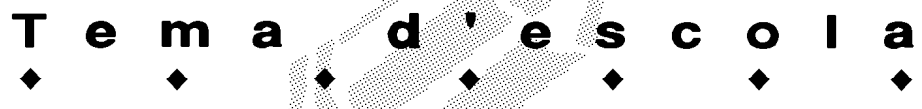

dar l'estudi des de les àrees indicades, a més de les Ciències Naturals i l'Educació per a la Salut i l'Educació Física. Una altra ens la presenten Nadal i Pérez (1991) donant apreciacions de l'àrea de les ciències en general.

Serà a partir d'aquestes vies que ens considerem deutors d'un seguit de treballs que han donat orientacions, en alguns casos amb propostes del tot suggerents. Aquests treballs sovint han anat encarats a reflexions teòriques, i en alguns casos, baixant a l'arena de l'educació, a presentar models més o menys amplis de com introduir-ho en l'escena educativa. Són dues perspectives diferents. La d'aquells que ho presenten des d'una base d'idees, de teoria sobre l'ús de la fotografia, amb ramificacions cap a l'àmbit escolar, i la d'aquells altres que han apostat decididament per presentar models encarats a l'aula, i a l'ús que se'n podria fer. Tanmateix, no agafarem aquells altres autors que aporten pautes per a l'anàlisi de la fotografia basats en la tècnica de saber fer fotografies, de components visuals -en variants de línia, figura, forma, textura, color-, de la il-luminació, la composició -des de pla general, pla de detall, picat i contrapicat- fins a l'enquadrament, aspectes que requeririen un altre enfocament respecte del que volem parlar (BORRÀS, GENÉ i VINAGRE, 2005).

En aquest primer àmbit teòric sobre les característiques del potencial de la fotografia trobem de manera rellevant Aparici i García (1989), els quals sostenen que la imatge a l'escola és vista com una mera transmissió, però no com un objecte de pensament i reflexió en si mateixa. A més de donar pautes de com llegir una imatge fixa, on inclouen la part connotativa o subjectiva, en el sentit que cal analitzar els missatges ocults, sostenen com a conclusions que cal educar a llegir la imatge, i ens adverteixen de les limitacions del mateix educador a l'hora de fer una lectura, ja que aquesta s'ha de fer obrint la ment de bat a bat. Afegeixen que la lectura d'imatges ha d'ajudar a crear en el lector filtres crítics que l'ajudin a evitar la manipulació.

En el segon àmbit, respecte de l'aplicació pràctica escolar, trobem també referències interessants. Vegemne algunes:

Iturrate (1996) alerta de no deixar l'estudi de l'estructura interna de la imatge i les interrelacions que s'hi estableixen. Espinagosa (2003) concreta l'exemplificació en models concrets, de forma que fa entendre l'ús de la fotografia en l'àmbit escolar, proposant treballs del tipus "La fotografia i la història urbana" o "La fotografia i l'arqueologia industrial”. Cerdà i Puig (1992) fan una proposta reflexiva sobre com trobar la idea principal d'una imatge. Parteixen de la base que les imatges s'han de fer parlar, i en conseqüència, cal posar un major èmfasi en el llenguatge oral. En aquesta apreciació la fotografia ha de ser el revulsiu per precisar textos breus, que primer passarien per concretar-se a allò que es veu, i que progressivament obligarien l'alumne a saber destriar la idea bàsica d'una imatge, a comprendre missatges/ idees expressades a partir de la imatge -buscant un llenguatge que li sigui propi-, a expressar una idea ordenadament i saber raonar i justificar una resposta pròpia en contrast amb altres plantejaments. A la llarga proposen que els alumnes, a través de la fotografia, a més de les idees principals i secundàries, han de saber discernir el sentiment que transmet la imatge. Biosca (2004) aporta una anàlisi reeixida de les imatges del franquisme. Des de l'àrea de les Ciències Socials -a secundària- recapacita sobre la interacció que es produeix en els alumnes en la recuperació de fotografies antigues, de familiars. Assegura que l'afany de voler saber més detalls d'aquests familiars, algunes vegades desconeguts, implica que l'alumne intenti relligar allò que se li explica amb continguts escolars. És el moment que aquesta imatge pot entrar a l'escola, i si per aquelles coses la persona -sempre anònima- encara viu, el testimoni agafa la categoria de font històrica. Explica que aquesta simbiosi entre fotografia i personatge, i una base prèvia d'estudi del període en qüestió, fa que es pugui buscar en la fotografia "detalls de l'escena, els personatges, el lloc, els objectes d'ús habitual, les novetats introduïdes en el si de la família, les anècdotes, i també el moment de la seva vida en què allò es va produir". Altrament assenyala unes pautes per conversar a partir de la fotografia: el paisatge, els personatges, els objectes, el flaix del moment, els costums i valors, i la idiosincràsia d'una època determinada.

Álvarez (2005) aborda la lectura de la imatge des de la vessant geogràfica, en la perspectiva de secundària. En sengles articles exposa la base teòrica d'autors precedents que sovint han insinuat preguntes a les quals no han trobat resposta. D'aquests autors n'agafa idees com que l'escola ha d'ensenyar a mirar, de manera rigorosa, per evitar ser víctima de prejudicis i de la manca de la capacitat de qüestionar-se a si mateix; que per aconseguir una mirada perspicaç s'han d'arbitrar tècniques de treball demostratiu que no s'aprèn des de la base del no-res; que els alumnes de primària no ensenyats no veuen la fotografia com una composició, sinó com un conjunt de peces individuals, sense sentit de proporció, fixant-se especialment en els detalls de forma; o que a preguntes banals se succeixen respostes del mateix calibre. L'estudi d'Álvarez, fet amb alumnes reals, planteja problemes previs a la imatge, del tot especificats; dóna claus de lectura i orienta les hipòtesis si es vol aprofundir en l'organització de l'espai a partir de la imatge. 


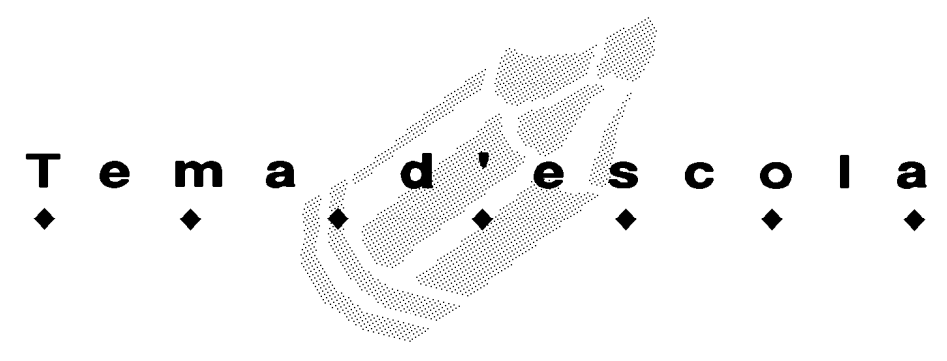

Qui aporta més elements d'anàlisi és Arqué (2004), la qual fins ha confegit una tesi doctoral sobre el tema, des de la perspectiva social. Sosté que no n'hi ha prou de posseir llibres il-lustrats, cintes de vídeo de totes les lliçons, de passar unes diapositives amb més o menys grapa sobre la unitat, sinó que cal demanar més al tractament de les imatges, que ajudin l'alumne a una formació sòlida d'habilitats i de conceptes socials. I sentencia que això es pot aconseguir per la via comunicativa, en un joc basat en el diàleg i en la participació.

Un dels molts aspectes suggerents que ens interessen ara aquí, l'exemplifica amb un quadre d'activitats d'aula amb una fotografia de paisatge, desgranant-lo en uns eixos de contingut. A partir de quatre grups d'activitat ens presenta deu blocs que justifiquen el que pot donar una fotografia preparada, per a una anàlisi en profunditat. Els deu eixos de contingut il-lustren la potencialitat de la lectura d'imatges:

- Com mirem els paisatges? Què sabem dels paisatges?

- L'organització dels elements en el paisatge.

- Una narració basada en el paisatge.

- Els plans en la fotografia de paisatge.

- Escala, perspectiva i punts de vista en el paisatge.

- Paisatge i color.

- Formes i línies en el paisatge.

- Els elements naturals del paisatge.

- Els paisatges humanitzats.

- Investigació a l'aula i registre fotogràfic.

Igual que Álvarez, presenta una anàlisi contrastada de la percepció del paisatge a alumnes de primària i de secundària, aspecte que li dóna peu a presentar una seqüència instructiva pròpia a partir dels quatre eixos d'activitats. Els sintetitzem, volgudament, en activitats d'aproximació, de lectura de paisatges, d'activitats d'anàlisi de paisatges, per acabar en una bateria de preguntes buscant la producció, l'enregistrament, la postanàlisi i la comunicació.

A aquests dos grans eixos d'anàlisi caldria afegir la percepció del que es pot aprendre. Són diversos els autors que ho han dit. Un de significat és Pró (2003), el qual ho basa en cinc eixos:

- Diversitat de llenguatges, que es concreta a ensenyar la capacitat de lectura, la descodificació dels missatges i la transformació en informació raonable.

- El desenvolupament de les capacitats d'observació. Serà necessària l'observació a l'espai, descriure llocs i formes, canvis de llum; l'observació en el temps, analitzant les transformacions de les coses, les estacions de l'any...; l'observació de les persones, la descripció física i el comportament.

- El desenvolupament de les estructures temporals.
Manifesta que s'ha d'acostumar els alumnes a aprendre l'organització temporal dels successos, la simultaneïtat d'uns fets determinats, la reflexió sobre un passat.

- Les estructures espacials. S'hauria d'aprendre la situació pròpia a l'espai, l'orientació en l'espai i la seva organització.

- Els processos d'abstracció i de generalització, a partir del que coneix per arribar a una visió pròpia del món.

\section{Un preprojecte pràctic d'entrada, amb la fotografia com a centre d'interès}

Pensem que la pràctica és la plasmació de la teoria feta realitat. Partint d'aquesta premissa sabem que sovint hi ha treballs que expliquen què s'ha de fer, com s'ha de fer i fins els resultats que se n'esperen. Dibuixen el procés, però no posen la pràctica real a discussió i es queden en un simulacre del que hauria de ser i com, malauradament sense concretar-ho. No volem caure en aquest parany.

Des de la perspectiva teòrica en què ens hem situat, volem aportar un primer esbós pràctic d'un aprenentatge eficient de la fotografia, útil per a una classe. El preprojecte de treball -el treball definitiu està en fase d'estudi-, el volem plantejar com una forma d'incidir en l'aula, en una actuació de mestre i alumne, en què el centre d'interès agafa carta de naturalesa i on el saber es configura com un tot integrat.

L'actuació que presentem és pensada per al cicle superior d'educació primària, tot i que la fem extensiva a secundària. Consegüentment, tot seguit plantejarem una proposta real del que podria ser un treball amb fotografies, partint de la base disciplinària per passar a una fase d'interrelació d'àrees. Conscients que aquest darrer procés és sovint més un neguit intencional sobre paper que una realitat efectiva, volem que la proposta presentada trenqui amb aquest aspecte. La fase d'estudi en què ens trobem implica que en el text de cada àrea es plantegi informació vàlida per a altres àrees, per arribar, finalment, treballant de forma interrelacionada, a un resultat cohesionat.

Presentat el model, estem en condicions de dissenyar un esquema sobre les possibilitats de treballar la fotografia a l'escola, esquema en fase de discussió i d'elaboració:

- Fotografia duta de l'alumne a la classe.

- Treball de procedència de la font.

- Conversa inicial sobre la fotografia.

- Lectura d'un text informatiu.

- Treball sistemàtic des de diverses àrees de treball.

- La disjuntiva del perquè referida a cada àrea. 


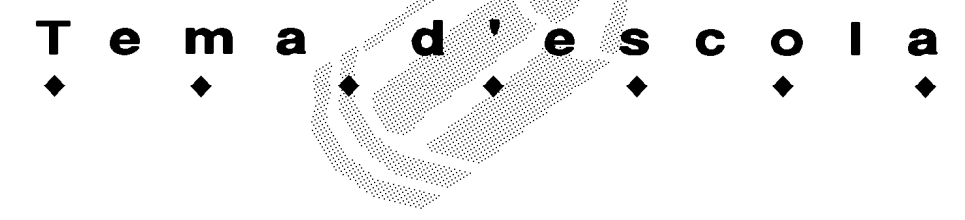

- Tancament del cicle des de la interrelació de diverses àrees.

- Avaluació del procés i resultats obtinguts.

Fotografia duta de l'alumne a la classe

La fotografia que presentem és extreta d'un àlbum particular, d'aquell que es té a les cases, d'una pràctica descriptiva a l'escola de Magisteri, en la qual un alumne va aportar una informació amb datació cronològica i d'enquadrament del text per referències familiars, sense cap més pretensió.

La fotografia s'ha incorporat al disseny de la concreció del model.

Les fotografies que recomanem que entrin a la classe han de demanar-se als alumnes en funció del que volem obtenir: com a eix central d'estudi d'un moment o una època determinada; com a complement d'una lliçó; com a aspecte específic d'un bloc de continguts, com podria ser la menja, els transports, el treball, les festes, les màquines... recordant que si és aquesta la demanda, serà millor especificar els períodes temporals concrets.

Cal tenir present que les fotografies que es poden demanar als alumnes, sobretot en alumnes de primària, com que seran comentades a la classe, cal demanar-les amb claredat a fi i efecte d'aprofitar el temps de treball.

Treball de procedència de la font

Les fotografies que s'utilitzaran per a aquest treball seran les que els alumnes portaran a classe. Aquestes hauran estat triades dels àlbums familiars. Abans d'iniciar el treball acadèmic serà necessària la implicació personal dels mateixos alumnes. La presentació de la fotografia escollida la farà el mateix alumne que l'ha portat. Aquest, oralment, donarà les primeres informacions sobre què s'hi veu, i que ell abans haurà preguntat a la seva família. També respondrà a les possibles qüestions que es derivin de la primera visualizació.

En aquest primer apartat es treballarien quatre aspectes, de forma oral:

- Coneixements previs que genera la fotografia en la resta d'alumnes.

- Memòria, intentant relacionar el que aporta la fotografia amb allò que se sap.

- Exposició oral, mirant que surtin tant aspectes que hi ha a la foto com suggeriments que genera la foto. Seria convenient parlar de l'abans i del després de la fotografia en qüestió.

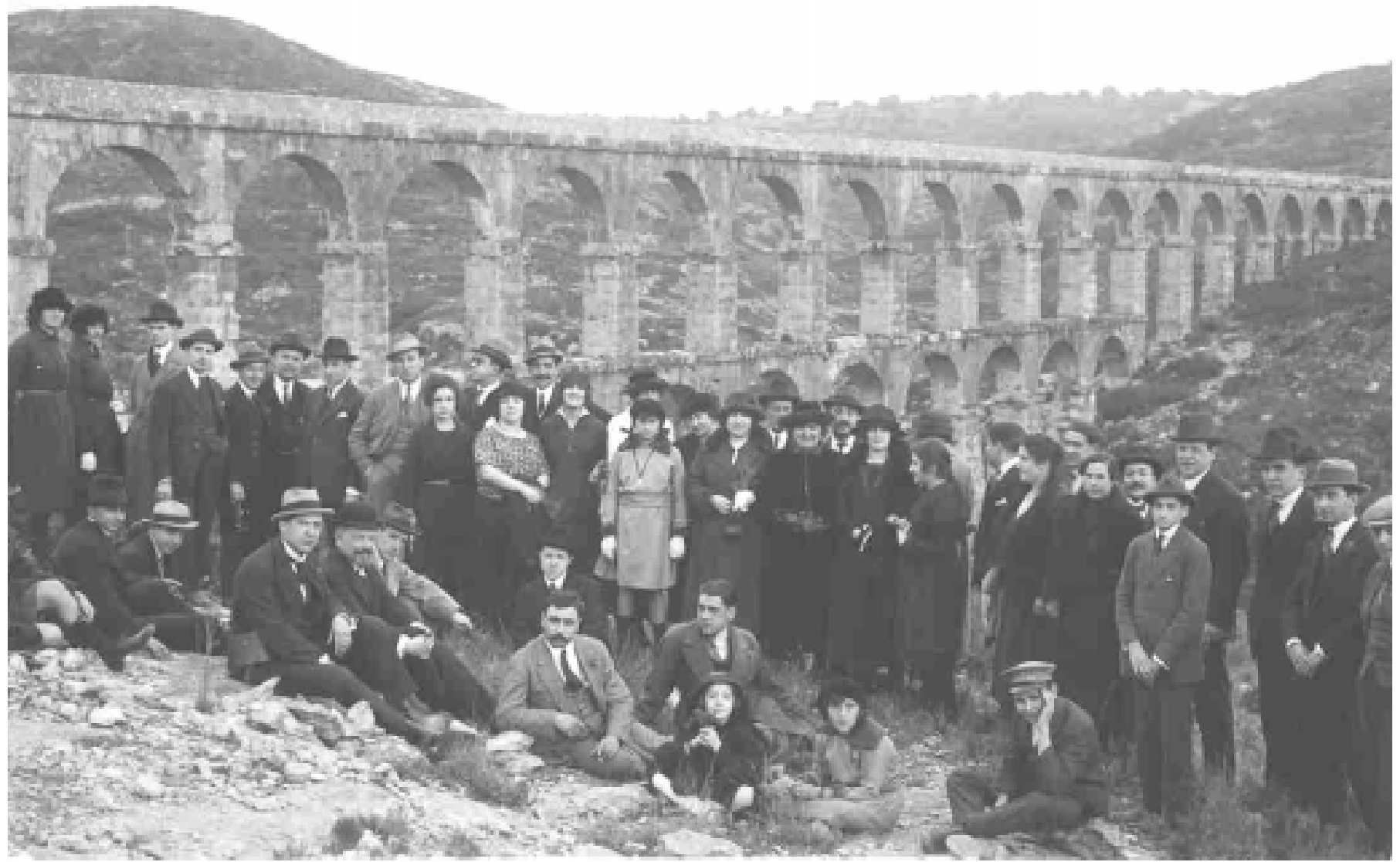

Fotografia 1. Visita al pont del Diable. 


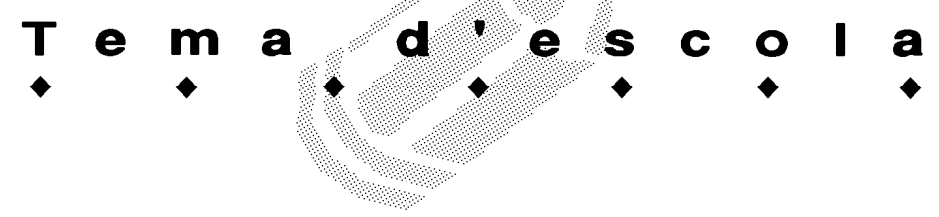

- Diàleg dirigit entre ells. Una conversa on el professor escolta, suggereix més que no parla.

Conversa inicial sobre la fotografia

El treball ara l'orientarà el professor. S'iniciarà la conversa intentant respondre a les preguntes bàsiques que normalment ens fem davant d'una imatge desconeguda, tot i que la conversa sobre la procedència de la fonts pot haver donat algunes pistes. S'haurà de tenir cura que les respostes que sorgeixin en la conversa donin la informació adequada, estimulin noves preguntes i que a la vegada assegurin que les propostes dels treballs de les diverses àrees es puguin resoldre correctament. Es basaran en tres eixos:

- Lectura de la imatge.

- Observació de detalls, de fenòmens.

- Construcció de hipòtesis (en el sentit d'inferències).

Les preguntes quasi inexcusables podrien ser:

- Qui hi ha en aquesta fotografia?

- On estan situats?

- Què fan?

- Quan sembla que va passar això?

Lectura d'un text informatiu

La fotografia duia una llegenda escrita per l'alumne, extreta oralment de les persones que la hi havien cedida. Aquest text s'emmarcaria amb unes breus ratlles, i la titularíem font. Aquestes ratlles -a títol de síntesi-podrien ser escrites pel professor o pels mateixos alumnes, realitzades en diferents formats -individual, grups-. Se segueixi el format que es cregui oportú, el text s'hauria de consensuar a la classe, i seria entès com un exercici de precisió conceptual.

El següent pas seria un text preparat pel professor per encaixar idees rellevants, i que després hauran de fer servir els alumnes en diferents exercicis. N'hi diríem text informatiu. El text informatiu es passaria a cada grup i es llegiria en veu alta. El text és pensat per deixar uns moments de preparació individual, de manera que els alumnes puguin controlar millor l'entonació i les pauses del text.

Una vegada acabada la lectura, es farien algunes preguntes de comprensió, amb les quals s'insistirà en aspectes importants per a la realització dels treballs posteriors.

\section{Concreció del model: primera aproximació}

Exposat el precedent, passem ara a l'explicitació d'un model per al cicle superior de primària, referit a una fotografia específica (vegeu la fotografia 1).

Font: Fotografia proporcionada per l'alumne Manel Lorenzo, on hi apareix un familiar seu que feia de guia a un grup de gent.

Text informatiu per a primària (Cicle Superior):

"Un grup de persones visiten el pont del Diable o de les Ferreres, als afores de la ciutat de Tarragona. Les indumentàries de la gent del grup revelen l'època en què va ser feta la fotografia, 1910, i que es tracta de persones que vestien elegantment. Moltes senyores i la majoria d'homes porten barrets, excepte un noi situat a la part inferior dreta de la fotografia, el qual porta una gorra de plat. Aquell personatge era un mosso que menava els cavalls des de Tarragona en excursions amb interès cultural.

El pont del Diable no era ben bé un pont, s'utilitzava amb la finalitat de transportar aigua cap a la ciutat romana de Tárraco. Es tracta d'un aqüeducte, que va ser construït fa uns 1900 anys. El seu nom, com en altres indrets de Catalunya, és producte de la fantasia popular."

Preguntes de comprensió lectora:

- Qui creus que són aquest grup de persones?

- On són?

- Què creus que fan?

- Quin és el nom d'aquest monument?

- Què vol dir aqüeducte?

- Qui va construir aquest pont?

- En quina època?

Seguidament, des de l'àrea de llengua d'educació primària s'incidiria en preguntes del tipus:

1. Com es diu la ciutat situada prop d'aquest monument?

2. El pont de la fotografia se'l coneix amb els noms de ...?

3. D'on deuen venir aquests noms?

4. Un dels dos noms sembla que surti d'un conte. De quin?

5. ¿Recordeu noms de llocs, pobles, construccions, etc. que portin el nom d'algun ésser imaginari? Digueu-los.

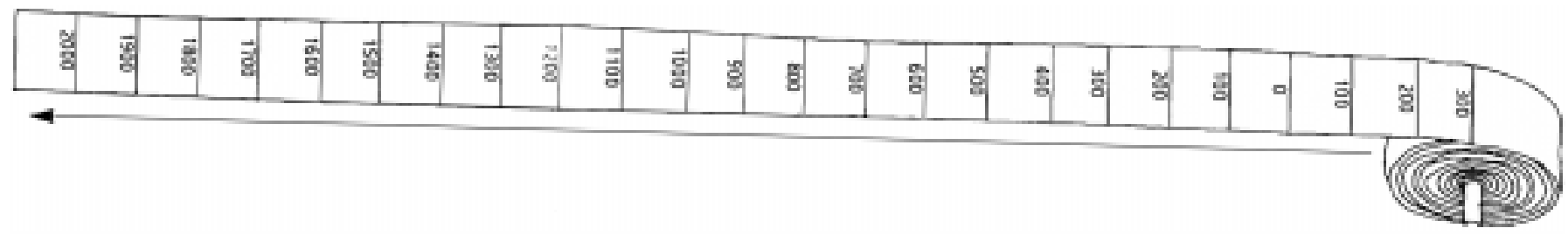

Figura 1. Línia del temps. 


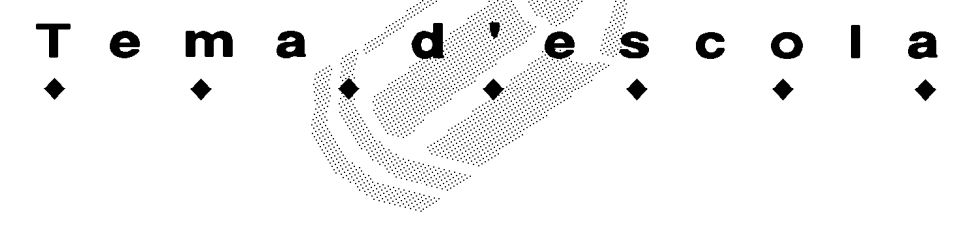

Treball sistemàtic des de diverses àrees de treball

El pas següent seria presentar la fotografia i un text pertinent per a una àrea d'estudi. En el nou text es presentaria, si convingués, un encaix per poder treballar l'àrea, mirant sempre que l'alumne retingués referències que poguessin ser recuperades per altres àrees.

Aquest seria el text i les qüestions a resoldre des de l'àrea de coneixement del medi natural:

La construcció que veus al fons de la imatge tenia la finalitat de transportar aigua fins a la ciutat de Tarragona. Aquesta construcció és prop de la riba del Francolí i es va fer ara fa uns 1900 anys.

Actualment rep el nom de pont del Diable o de les Ferreres. Els aqüeductes com aquest es van utilitzar fins ben entrada l'edat mitjana.

1. El pont del Diable portava aigua cap a Tarragona. Normalment l'aigua la trobes a la natura en l'estat líquid. Digues altres formes de presentació de l'aigua a la natura.
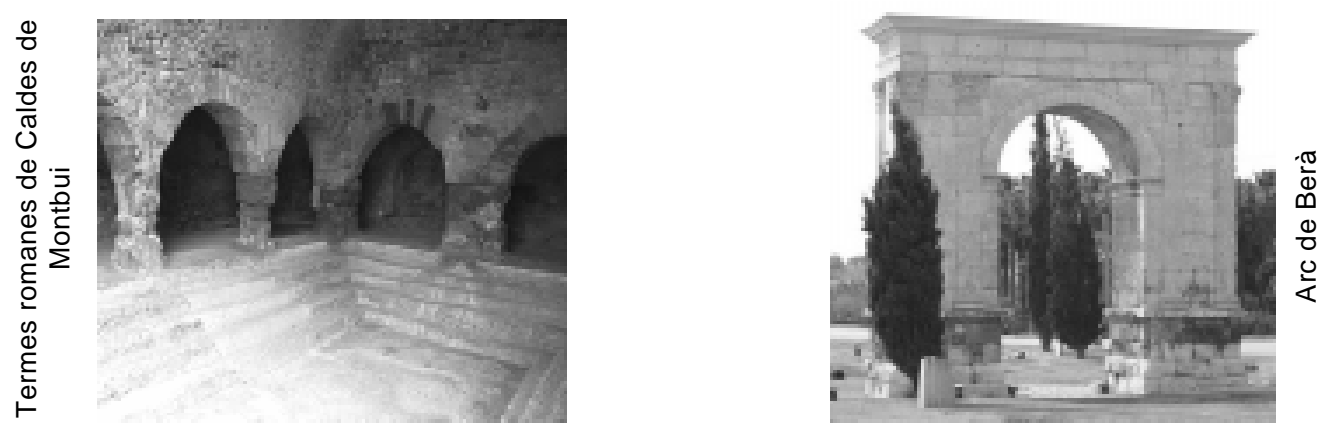

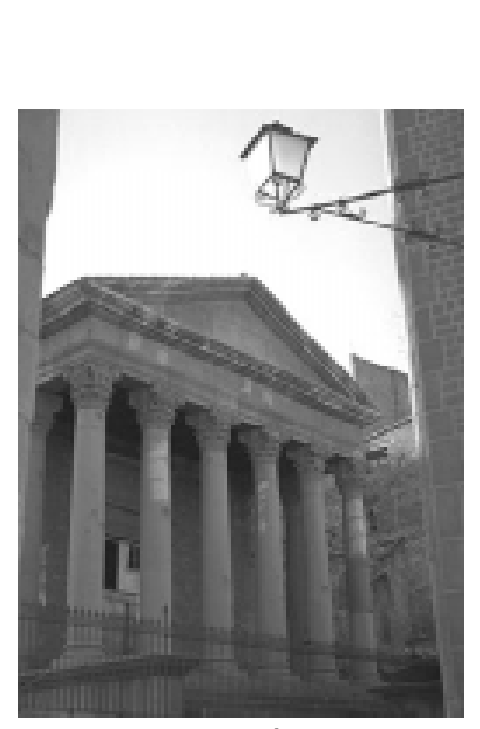

Temple Romà de Vic

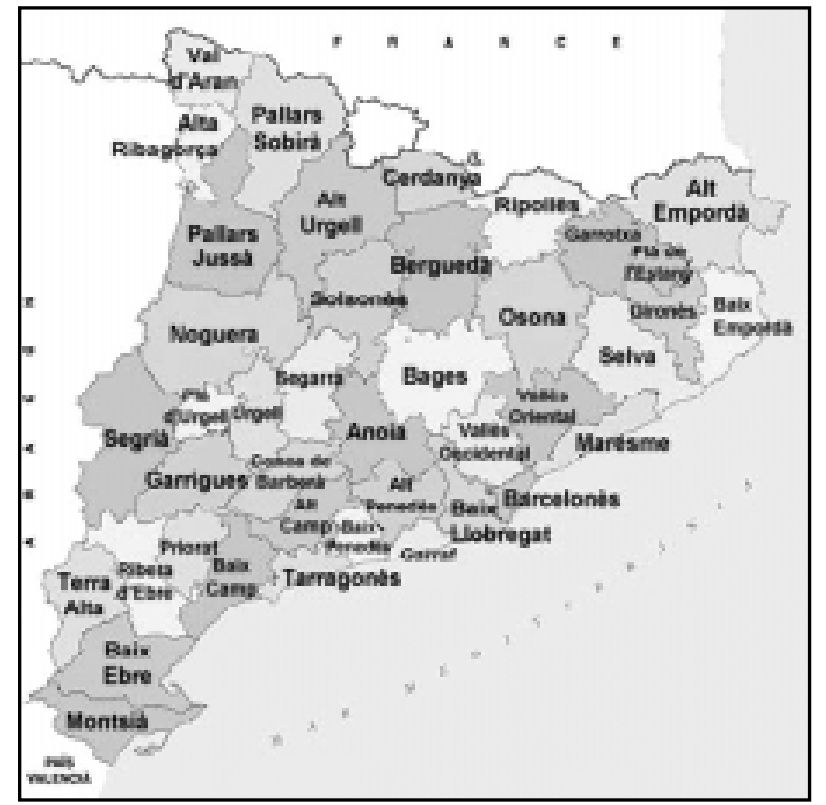

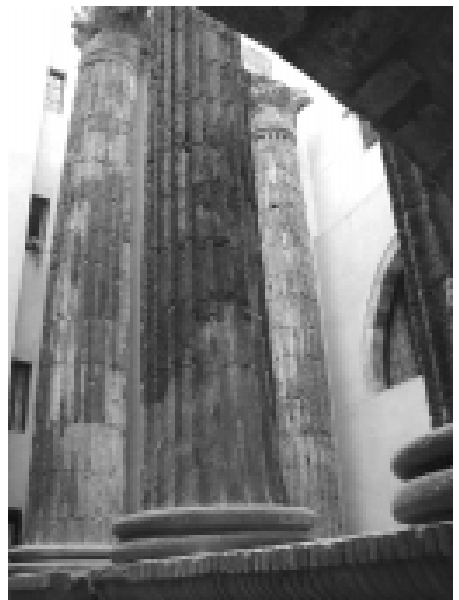

Columnes del temple d'August de Barcelona
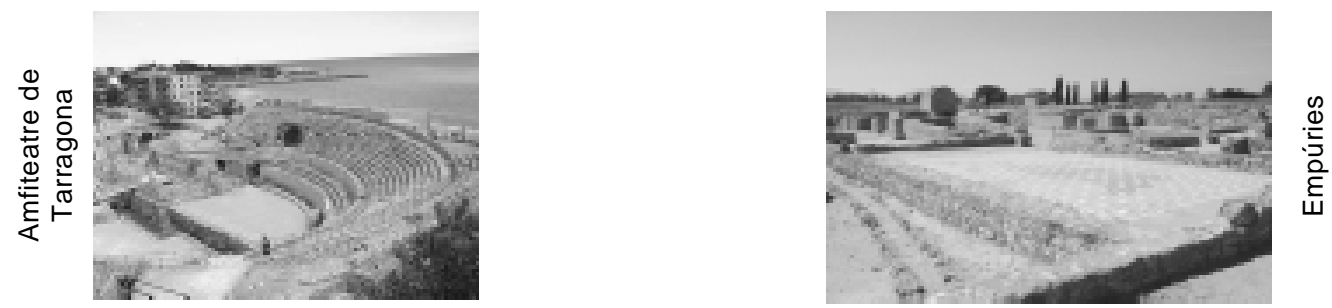

Figura 2. Alguns edificis i construccions romanes a Catalunya. 


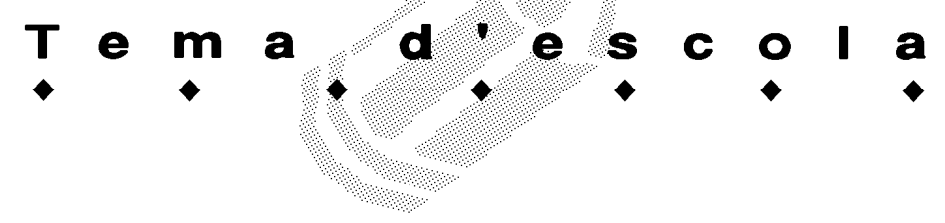

2. Possiblement ja saps que l'aigua s'evapora per efecte del vent i del sol.

3. Ara faràs la següent experiència: Posa el mateix volum d'aigua en dos plats iguals. Un el poses a dins de l'aula, i l'altre el deixes a la finestra de forma que estigui a l'exterior. Controla en quin dels plats l'aigua s'evapora més ràpidament.

4. Ja saps que l'aigua cada dia és més escassa. Digues dues coses que tu pots fer per estalviar aigua.

I a continuació van les activitats referides a l'àrea de coneixement del medi social i cultural:

1. Dibuixa en color en la línia del temps (vegeu la figura 1) el període de dominació romana de les terres que avui són Catalunya. Tingues en compte que els romans van desembarcar a Empúries el 218 abans de la nostra era i que l'imperi romà d'Occident va quedar enderrocat a finals del segle $\mathrm{V}$. Situa a continuació l'any 1910 , en què va ser feta la fotografia de l'excursió del pont del Diable.

2. Situa els següents edificis i construccions romanes al mapa. Fes una fletxa que surti de cada fotografia i acabi en l'indret de Catalunya on es troba (vegeu la figura 2).

3. La imatge del pont del Diable ens mostra un indret amb un clima mediterrani. A partir del que veus, digues si es tracta d'un clima plujós o no. També raona si en un clima com aquest era necessari fer obres per portar aigua a una gran ciutat com era Tárraco.

Aquest exemple es completaria amb les activitats $\mathrm{i}$ qüestions plantejades des de la resta d'àrees (educació artística: visual i plàstica, i educació física).

La disjuntiva del perquè referida a cada àrea

Les qüestions que es presenten per àrees han de tenir una lògica dins del currículum establert. En definitiva, cal saber per què es fan i quina competència han d'assolir els alumnes. Si seguim amb les àrees de Ciències Experimentals i Ciències Socials, trobem que els ítems anteriors tenen una lògica educativa que volem reflectir. Les referides a l'àrea de Ciències Experimentals les trobareu a la taula 1 , mentre que les de Ciències Socials són a la taula 2.

El que fins ara s'ha descrit és la situació en la qual ens trobem en aquests moments. Esperem completar els apartats que queden pendents ("Tancament del cicle des de la interrelació de diverses àrees", i "Avaluació del procés i resultats obtinguts"), i oferir-vos el treball complet de recerca ben aviat.

\begin{tabular}{|c|c|c|}
\hline Activitat número & Intencionalitat & Competència a assolir \\
\hline 1 & $\begin{array}{l}\text { - Es pretén que l'alumne descrigui els tres es- } \\
\text { tats en què es troba l'aigua a la natura: líquid, } \\
\text { vapor i sòlid. } \\
\text { - S'ha de fugir de la idea que un dels estats de } \\
\text { l'aigua és el gasós. L'estat vapor i el gasós } \\
\text { són semblants en algunes propietats, però di- } \\
\text { ferents en altres. }\end{array}$ & $\begin{array}{l}\text { - Adequada percepció de l'espai físic en què es } \\
\text { desenvolupa la vida i l'activitat humana, tant a } \\
\text { gran escala com a l'entorn immediat. } \\
\text { - Apropiació de conceptes que permeten inter- } \\
\text { pretar el món físic. }\end{array}$ \\
\hline 2 & $\begin{array}{l}\text { - Es tracta que l'alumne s'adoni que l'aigua } \\
\text { líquida s'evapora, i que la rapidesa amb què } \\
\text { s'evapora augmenta amb la temperatura i la } \\
\text { "ventilació". }\end{array}$ & $\begin{array}{l}\text { - Obtenir conclusions basades en proves, amb la } \\
\text { finalitat de comprendre el món físic. } \\
\text { - Adquirir l'habilitat progressiva per posar en } \\
\text { pràctica els processos i actituds propis de l'anàlisi } \\
\text { sistemàtica i indagació científica. }\end{array}$ \\
\hline 3 & $\begin{array}{l}\text { S'intenta que l'alumne s'adoni de la impor- } \\
\text { tància de l'aigua en el desenvolupament de la } \\
\text { vida humana i de la necessitat de fer-ne un } \\
\text { ús responsable. }\end{array}$ & $\begin{array}{l}\text { - Ser conscient de la influència que té la presència } \\
\text { de les persones i les modificacions que intro- } \\
\text { dueixen en el medi natural. } \\
\text { - Comprendre i prendre decisions sobre el canvi } \\
\text { que l'activitat humana produeix en el medi am- } \\
\text { bient. }\end{array}$ \\
\hline
\end{tabular}




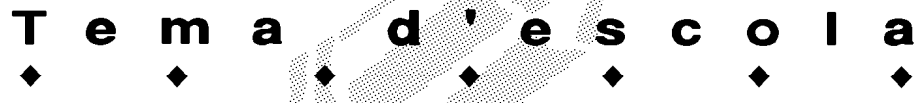

\section{Referències bibliogràfiques}

ALVAREZ ORELLANA, MARÍA F. El mapa conceptual en la interpretación de las fotografías. II Congreso Ibérico de Didáctica de la Geografía. Associaçao de Profesores de Geografia y Grupo de Didáctica de la AGR. Lisboa. 2005.

APARICI MARINO, ROBERTO; GARCÍA MATILLA, AGUSTÍN. Lectura de imágenes. Ediciones de la Torre. Madrid. 1989.

ARQUÉ, MAITE. La imatge visual en la didàctica de les Ciències Socials. Tesi doctoral inèdita. Universitat de Barcelona. 2004.

BAZALGETTE, C. Los medios audiovisuales en la educación primaria. Edit. Morata/MEC. Madrid. 1991.

BIOSCA, GENONA. Imatges que parlen del franquisme. De la fotografia als records. Un projecte a 4t. d'ESO que estimula les relacions intergeneracionals. "Escola Catalana», 39,413 (2004) 39-44.

BORRÀS CARLES, P.; GENÉ ROSA, J.; VINAGRE HERNÁNDEZ, G. La fotografia a l'aula. Edit. Servei de Difusió i Publicacions. Departament d'Educació. Generalitat de Catalunya. Barcelona. 2005.

BROWN, W; i altres. Instrucción audiovidual. Tecnología, medios y métodos. México. 1975.

CAMPUZANO RUIZ, ANTONIO. Tecnologías audiovisuales y educación. Una visión desde la práctica. Edit. Akal. Madrid. 1992.
CERDÀ, MONTSERRAT; PUIG, MARTA. Com trobar la idea principal d'una imatge. «Escola Catalana», 286 (1992).

ESPINAGOSA MARSÀ, JAUME. Fotografia per a la història. Seminaris Departament de Geografia i Història de I'IEI. Institut d'Estudis Ilerdencs. Lleida. 2003.

FONTCUBERTA i VILÀ, JOAN. Fotografía: conceptos y procedimientos. Una propuesta metodológica. Edit. G. Gili. Barcelona. 1990.

La imatge i la recerca històrica. Ponències i comunicacions. 8es. Jornades Antoni Varés, del 16-19 de novembre de 2004. Ajuntament de Girona. 2004.

ITURRATE, GERMÀ; i altres. Les fonts en les ciències socials. Edit. Graó. Barcelona. 1996.

NADAL MARTÍN, M. ÀNGELS; PÉREZ CELADA, VICTÒRIA. Los medios auxiliares al servicio del Centro Educativo. Edit. MEC. Madrid. 1991.

PRÓ, MAITE. Aprender con imágenes. Incidencia y uso de la imagen en las estrategias de aprendizaje. Edit. Paidós. Barcelona. 2003.

SANTOS GUERRA, MIGUEL ÁNGEL. Imagen y Educación. Edit. Anaya/2. Madrid. 1984.

TENORIO VÁZQUEZ, IRENE. El problema del contenido informativo de la fotografía y su análisis. A REY DE LAS PEÑAS, REMEDIOS. La fotografía como fuente de información. Foro Iberoamericano de la Rábida. Palos de la Frontera. Huelva. Diputación Provincial de Huelva. Huelva. 1995.

\begin{tabular}{|c|c|c|}
\hline Activitat número & Intencionalitat & Competència a assolir \\
\hline 1 & $\begin{array}{l}\text { - Treballar els canvis en el temps. } \\
\text { - Posar en pràctica les convencions de datació } \\
\text { i periodització. } \\
\text { - Fer-los adonar que la romanització va ser en } \\
\text { un període de temps molt allunyat. }\end{array}$ & - Coneixement i interacció amb el món físic. \\
\hline 2 & $\begin{array}{l}\text { - Conèixer algunes de les restes romanes més } \\
\text { representatives que han quedat a Catalunya. } \\
\text { - Fer-los adonar que la romanització va afectar } \\
\text { més les zones més properes a la costa, ja que } \\
\text { és on hi ha més vestigis romans. }\end{array}$ & $\begin{array}{l}\text { - Coneixement i interacció amb el món físic. } \\
\text { - Artística i cultural. }\end{array}$ \\
\hline 3 & $\begin{array}{l}\text { - Que coneguin la influència del clima en el } \\
\text { paisatge. } \\
\text { - Que relacionin escassetat d'aigua amb la ne- } \\
\text { cessitat de fer obres de conducció d'aigua } \\
\text { cap a les ciutats. }\end{array}$ & - Coneixement i interacció amb el món físic. \\
\hline
\end{tabular}

Taula 1. Finalitats i competències de l'àrea de Ciències Socials. 